\title{
EFFECT OF COPPER ON THE TOXICITY AND GENOTOXICITY OF CADMIUM IN DUCKWEED (LEMNA MINOR L.)
}

\author{
Petra CVJETKO ${ }^{1}$, Sonja TOLIĆ ${ }^{2}$, Sandra ŠIKIĆ ${ }^{2}$, Biljana BALEN ${ }^{1}$, Mirta TKALEC ${ }^{3}$, \\ Željka VIDAKOVIĆ-CIFREK ${ }^{3}$, and Mirjana PAVLICA ${ }^{1}$
}

Department of Molecular Biology, Faculty of Science, University of Zagreb ${ }^{1}$, Department of Ecology, Institute of Public Health ${ }^{2}$, Department of Botany, Faculty of Science, University of Zagreb ${ }^{3}$, Zagreb, Croatia

Received in July 2010

Accepted in August 2010

\begin{abstract}
We investigated interactions between copper (in the concentrations of $2.5 \mu \mathrm{mol} \mathrm{L}^{-1}$ and $5 \mu \mathrm{mol} \mathrm{L}^{-1}$ ) and cadmium $\left(5 \mu \mathrm{mol} \mathrm{L}^{-1}\right)$ in common duckweed (Lemna minor L.) by exposing it to either metal or to their combinations for four or seven days. Their uptake increased with time, but it was lower in plants treated with combinations of metals than in plants treated with either metal given alone. In separate treatments, either metal increased malondialdehyde (MDA) level and catalase and peroxidase activity. Both induced DNA damage, but copper did it only after 7 days of treatment. On day 4 , the combination of cadmium and $5 \mu \mathrm{mol} \mathrm{L}^{-1}$ copper additionally increased MDA as well as catalase and peroxidase activity. In contrast, on day 7, MDA dropped in plants treated with combinations of metals, and especially with $2.5 \mu \mathrm{mol} \mathrm{L} \mathrm{L}^{-1}$ copper plus cadmium. In these plants, catalase activity was higher than in copper treated plants. Peroxidase activity increased after treatment with cadmium and $2.5 \mu \mathrm{mol} \mathrm{\textrm {L } ^ { - 1 }}$ copper but decreased in plants treated with cadmium and $5 \mu \mathrm{mol} \mathrm{L}^{-1}$ copper. Compared to copper alone, combinations of metals enhanced DNA damage after 4 days of treatment but it dropped on day 7. In conclusion, either metal given alone was toxic/ genotoxic and caused oxidative stress. On day 4 of combined treatment, the higher copper concentration was more toxic than either metal alone. In contrast, on day 7 of combined treatment, the lower copper concentration showed lower oxidative and DNA damage. These complex interactions can not be explained by simple antagonism and/or synergism. Further studies should go in that direction.
\end{abstract}

KEY WORDS: aquatic plants, DNA damage, ecotoxicological testing, heavy metals, oxidative stress

Heavy metals are very persistent natural or anthropogenic pollutants, especially in the aquatic environment. Most are toxic and indirectly genotoxic to various organisms. The biological effects of individual metals are more or less known, but even though combinations of heavy metals are common in nature their combined effects are still to be thoroughly investigated $(1,2)$. Metals in mixtures may act independently or interact to produce additive, synergistic, or antagonistic effects, which depends on their concentrations and factors such as temperature,
$\mathrm{pH}$, and light (2). In general, these interaction effects do not fit the toxicological profiles of individual metals making a combination.

Cadmium (Cd) is one of the most toxic metals, and is also genotoxic for most plant and animal organisms (1-4). It is released into the environment through industrial wastewater and other waste. It accumulates in the soil, water, and sediment. Cd induces tumours in exposed experimental animals and human cell lines (4). However, the molecular mechanism of $\mathrm{Cd}$ genotoxicity is still unclear. Cd genotoxicity could 
be induced directly by its interaction with DNA or by inhibition of essential mismatch repair, both causing genetic instability (4). Moreover, Cd can induce oxidative stress and can damage biological macromolecules such as lipids, proteins and DNA through reactive oxygen species (ROS) (5). In plants, $\mathrm{Cd}$ induces DNA damage (6) directly or indirectly by inducing oxidative stress (7). $\mathrm{Cd}$ can also affect the photosynthetic apparatus $(8,9)$, as well as the respiratory and nitrogen metabolism, which results in growth retardation, leaf chlorosis, water and nutrient imbalances, and the production of ROS (3). Unlike $\mathrm{Cd}$, copper $(\mathrm{Cu})$ at low concentrations is essential for numerous physiological processes. Its concentration in soil solution for optimal growth of most plant species is in the range of $10^{-3} \mu \mathrm{mol} \mathrm{L}^{-1}$ to $1 \mu \mathrm{mol} \mathrm{L}^{-1}$ (10). However at high concentrations it inhibits root growth, induces chlorosis, necrosis, and leaf discoloration, and disturbs very important cell processes (11). Moreover, it can damage cell membranes and induce lipid peroxidation since $\mathrm{Cu}$, like other heavy metals, induces oxidative stress $(12,13)$.

Chemical and physical analytical methods are useful for detecting the presence and the concentration of chemicals in the environment, but these methods do not include biological component. Plants are routinely used for biological monitoring of xenobiotics (14, $15)$. Among them, macrophytes are very suitable for toxicology testing, family Lemnaceae in particular. The advantage of aquatic macrophytes over terrestrial plants is that macrophytes are exposed not only through the root, but also through the leaf. Aquatic macrophytes duckweeds have commonly been used to test the toxicity of heavy metals (16) because they are very easy to culture in the laboratory. Their growth rate is high and so is sensitivity to different pollutants. Aquatic plants are of special environmental concern, as they biofilter toxic elements (17). In recent years, interest has been focused on using aquatic plants, such as Lemna minor, Microspora, and Pistia stratiotes, as a promising approach to take up heavy metals from water body $(18,19)$. Lemna minor L., also known as common duckweed, is often used in ecotoxicological testing as a representative of higher aquatic plants (20).

So far, only a few studies have investigated combined effects of metals on plant species (1). The aim of our study was to investigate whether $\mathrm{Cu}$, as an essential element, interacted with the toxicity and genotoxicity of $\mathrm{Cd}$, a non-essential metal, in aquatic plant Lemna minor L. (duckweed).

\section{MATERIALS AND METHODS}

\section{Plant material and culture conditions}

Lemna minor L. stock culture was maintained on a Pirson and Seidel nutrient medium (21). For the experiment the plants were grown in sterilised Steinberg medium (22) at $(24 \pm 1){ }^{\circ} \mathrm{C}$, with a 16 -hour light $\left(40 \mu \mathrm{E} \mathrm{m}^{-2} \mathrm{~s}^{-1}\right)$ and 8-hour dark cycle.

\section{$\mathrm{Cd}$ and $\mathrm{Cu}$ treatment}

Approximately 10 colonies of healthy duckweed were transferred into a $300 \mathrm{~mL}$ Erlenmeyer flask containing $100 \mathrm{~mL}$ of Steinberg nutrient solution with $\mathrm{Cd}$ (in the form of $\mathrm{CdCl}_{2}$; Fluka, Switzerland) at the concentration of $5.0 \mu \mathrm{mol} \mathrm{L}^{-1}$ and $/ \mathrm{or} \mathrm{Cu}$ (in the form of $\mathrm{CuCl}_{2}$; Kemika, Croatia) at $2.5 \mu \mathrm{mol} \mathrm{L}^{-1}$ or $5.0 \mu \mathrm{mol} \mathrm{L}^{-1}$. Plants grown on Steinberg medium alone were used as control. Metal content, lipid peroxidation, carbonyl content, comet assay, catalase (CAT) and peroxidase (POD) activities in duckweed fronds were determined on days 4 and 7 of exposure.

\section{Determination of $\mathrm{Cu}$ and $\mathrm{Cd}$ content}

Plants were oven-dried at $80^{\circ} \mathrm{C}$ for $24 \mathrm{~h}$ until a constant weight was achieved. Plant tissue was then microwave digested in two steps. The first digestion step was digestion in $10 \mathrm{~mL}$ of concentrated $\mathrm{HNO}_{3}$ $\left(16 \mathrm{mmol} \mathrm{L}^{-1}\right.$; Kemika, Croatia) at $70{ }^{\circ} \mathrm{C}$ for $5 \mathrm{~min}$, then at $130{ }^{\circ} \mathrm{C}$ for another $5 \mathrm{~min}$ and finally at $150{ }^{\circ} \mathrm{C}$ for $4 \mathrm{~min}$. The second step was digestion in $1 \mathrm{~mL}$ of $\mathrm{H}_{2} \mathrm{O}_{2}$ (Kemika, Croatia) at $85^{\circ} \mathrm{C}$ for 5 min and then at $130{ }^{\circ} \mathrm{C}$ for $4 \mathrm{~min}$. After cooling, the samples were diluted with $1 \%(\mathrm{v} / \mathrm{v}) \mathrm{HNO}_{3}$ up to the total volume of $50 \mathrm{~mL}$. Cadmium and copper were analysed using inductively coupled plasma-Optical Emission Spectroscopy (ICP-OES, IRIS INTREPID II XSP 9597 - Thermo Elemental, USA) according to the HRN EN ISO 11885:1998 standard. The results were processed using TEVA software /firmware version 1.5.0/1.5.0 (Thermo Elemental Validated Analysis, Thermo Electron Corporation, USA). Metal concentrations were calculated according to the calibration curve obtained with a set of standards of known concentrations (Merck, Germany). For cadmium we used a lower concentration range of $1 \mu \mathrm{g} \mathrm{L}^{-1}$ to $50 \mu \mathrm{g} \mathrm{L}^{-1}$, and for copper a higher concentration range of $50 \mu \mathrm{g} \mathrm{L}^{-1}$ to $5,000 \mu \mathrm{g} \mathrm{L}^{-1}$. Detection limits for $\mathrm{Cd}$ and $\mathrm{Cu}$ were $0.5 \mu \mathrm{g} \mathrm{kg}^{-1}$ and $10 \mu \mathrm{g} \mathrm{kg}^{-1}$, respectively. The limit of quantification (LOQ) was $<1 \mu \mathrm{g} \mathrm{kg}^{-1}$ and $<20 \mu \mathrm{g} \mathrm{kg}^{-1}$, respectively. 


\section{Malondialdehyde and carbonyl content}

Lipid peroxidation was determined by measuring the amount of malondialdehyde (MDA), a product of lipid peroxidation, according to a modified method of Heath and Packer (23). Treated plants (50 mg fresh weight) were homogenised in $1 \mathrm{~mL}$ of $0.25 \%$ (w/v) 2-thiobarbituric acid (TBA, Sigma, Germany) in $10 \%$ trichloroacetic acid (TCA, Kemika, Croatia), and incubated at $95{ }^{\circ} \mathrm{C}$ for $30 \mathrm{~min}$. The tubes were then transferred into an ice bath and centrifuged at $15,000 \mathrm{~g}$ and $+4{ }^{\circ} \mathrm{C}$ for $10 \mathrm{~min}$. The absorbance of the supernatant was recorded at $532 \mathrm{~nm}$ and corrected for non-specific turbidity by subtracting the absorbance at $600 \mathrm{~nm}$. For a blank we used $0.25 \%$ TBA in $10 \%$ TCA. The content of MDA was expressed as micromol per gram of fresh weight $\left(\mu \mathrm{mol} \mathrm{g}^{-1}\right)$ using an extinction coefficient of $155 \mathrm{~L} \mathrm{mmol}^{-1} \mathrm{~cm}^{-1}$.

For carbonyl quantification, the reaction with 2,4dinitrophenylhydrazine (DNPH, Aldrich, Germany) was used basically as described by Levine et al. (24). Fresh plant tissue $(80 \mathrm{mg}$ ) was homogenised in $1 \mathrm{~mL}$ of $10 \mathrm{mmol} \mathrm{L}^{-1}$ potassium phosphate buffer ( $\mathrm{pH} 7.4$ ), which contained $1 \mathrm{mmol} \mathrm{L}^{-1}$ ethylenediaminetetraacetic acid (EDTA, Merck, Germany) and polyvinylpyrrolidone (PVP, Sigma, Germany). After centrifugation at $20,000 \mathrm{~g}$ and $+4{ }^{\circ} \mathrm{C}$ for $20 \mathrm{~min}$, the supernatants $(200 \mu \mathrm{L})$ were combined with $300 \mu \mathrm{L}$ of $10 \mathrm{mmol} \mathrm{L}^{-1}$ DNPH in $2 \mathrm{~mol} \mathrm{~L}^{-1} \mathrm{HCl}$ (Kemika, Croatia). After 1hour incubation at room temperature, the proteins were precipitated with $500 \mu \mathrm{L}$ of cold $10 \%(\mathrm{w} / \mathrm{v})$ TCA. Samples were cooled to $-20^{\circ} \mathrm{C}$ and then centrifuged at $12,000 \mathrm{~g}$ and $+4{ }^{\circ} \mathrm{C}$ for $10 \mathrm{~min}$. The pellets were washed three times with $500 \mu \mathrm{L}$ of ethanol/ethylacetate $(1: 1, \mathrm{v} / \mathrm{v})$ to remove excess reagent. The precipitated proteins were finally dissolved in $6 \mathrm{~mol} \mathrm{~L}^{-1}$ urea in $20 \mathrm{mmol} \mathrm{L}^{-1}$ potassium phosphate buffer ( $\left.\mathrm{pH} 2.4\right)$ in an ultrasonic bath. Absorbance was measured at $370 \mathrm{~nm}$. Protein recovery was estimated for each sample by measuring the absorbance at $280 \mathrm{~nm}$. Carbonyl content was calculated using a molar absorption coefficient for aliphatic hydrazones of $22 \mathrm{~L} \mathrm{mmol}^{-1} \mathrm{~cm}^{-1}$ and expressed as micromol per milligram of proteins

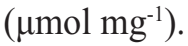

\section{Comet assay}

For the genotoxicity assessment, we used an alkaline version of the cellular comet assay following the protocol by Gichner et al. (6) with a slight modification (10 min denaturation, 10 min electrophoresis at $0.72 \mathrm{~V} \mathrm{~cm}^{-1}$ and $300 \mathrm{~mA}$ ). Duckweed leaves were placed in a $60 \mathrm{~mm}$ diameter Petri dish containing $200 \mathrm{~mL}$ of ice-cold $400 \mathrm{mmol} \mathrm{L}^{-1}$ Tris/HCl buffer (Kemika, Croatia; $\mathrm{pH}$ 7.5) and cut into small pieces with a sterile razor blade to isolate the nuclei. Fifty randomly chosen nuclei per treatment from two independent experiments were analysed under a fluorescent microscope (Zeiss Axioplane) equipped with an excitation filter BP 520/09 $\mathrm{nm}$ and a barrier filter of $610 \mathrm{~nm}$. A computerised image analysis system (Komet version 5, Kinetic Imaging Ltd., Liverpool, UK) was used to measure percentage of tail DNA (\% tDNA).

\section{Enzyme activity assays}

Plants $(80 \mathrm{mg}$ ) were homogenised in $1 \mathrm{~mL}$ of cold $50 \mathrm{mmol} \mathrm{L}^{-1}$ potassium phosphate buffer (Kemika, Croatia; $\mathrm{pH} 7.0$ ), containing $0.1 \mathrm{mmol} \mathrm{L}^{-1}$ EDTA and PVP. The homogenate was centrifuged at 20,000 $\mathrm{g}$ and $+4{ }^{\circ} \mathrm{C}$ for $30 \mathrm{~min}$ and the supernatant was used for the CAT and POD enzyme assays.

CAT (EC 1.11.1.6) activity was evaluated spectrophotometrically (25) by measuring the decrease in $\mathrm{H}_{2} \mathrm{O}_{2}$ absorbance at $240 \mathrm{~nm}\left(\varepsilon=36 \mathrm{~L} \mathrm{mmol}^{-1} \mathrm{~cm}^{-1}\right)$ every $10 \mathrm{~s}$ for $2 \mathrm{~min}$. The reaction mixture consisted of $50 \mathrm{mmol} \mathrm{L}^{-1}$ of potassium phosphate buffer $(\mathrm{pH}$ 7.0), $10 \mathrm{mmol} \mathrm{L}^{-1}$ of $\mathrm{H}_{2} \mathrm{O}_{2}$, and $50 \mu \mathrm{L}$ of enzyme extract. CAT activity was expressed as micromol of decomposed $\mathrm{H}_{2} \mathrm{O}_{2}$ per minute per milligram of proteins $\left(\mu \mathrm{mol} \mathrm{min}{ }^{-1} \mathrm{mg}^{-1}\right)$. For CAT in-gel detection, the gels were incubated in distilled water for $45 \mathrm{~min}$ and then in $\mathrm{H}_{2} \mathrm{O}_{2}$ solution $(0.003 \%$, v/v) for $10 \mathrm{~min}$. The gels were then washed in distilled water and stained in a 1:1 mixture of $2 \%(\mathrm{w} / \mathrm{v}) \mathrm{FeCl}_{3}$ and $2 \%(\mathrm{w} / \mathrm{v}) \mathrm{K}_{3} \mathrm{Fe}(\mathrm{CN})_{6}$ (Kemika, Croatia) for $10 \mathrm{~min}$ (26).

POD activity was determined spectrophotometrically by measuring the increase in absorbance at $470 \mathrm{~nm}$ $\left(\varepsilon=26.6 \mathrm{~L} \mathrm{mmol}^{-1} \mathrm{~cm}^{-1}\right)$ every $15 \mathrm{~s}$ for $2.5 \mathrm{~min}$. The reaction mixture consisted of $50 \mathrm{mmol} \mathrm{L}^{-1}$ of potassium phosphate buffer ( $\mathrm{pH} 7.0), 18 \mathrm{mmol} \mathrm{L}^{-1}$ of guaiacol (Sigma, Germany), $5 \mathrm{mmol} \mathrm{L}^{-1}$ of $\mathrm{H}_{2} \mathrm{O}_{2}$ (27), and $50 \mu \mathrm{L}$ of enzyme extract. POD activity was expressed as micromol of formed tetraguiacol per

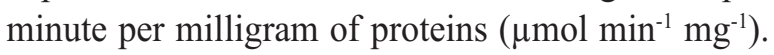
For POD in-gel detection, the gels were equilibrated with $50 \mathrm{mmol} \mathrm{L}^{-1}$ potassium phosphate buffer $(\mathrm{pH}$ 7.0) for $30 \mathrm{~min}$ and then incubated in $50 \mathrm{mmol} \mathrm{L}^{-1}$ potassium phosphate buffer $(\mathrm{pH} 7.0)$ containing $20 \mathrm{mmol} \mathrm{L}^{-1}$ pyrogallol and $4 \mathrm{mmol} \mathrm{L}^{-1} \mathrm{H}_{2} \mathrm{O}_{2}$ until brown bands appeared (27). 
Soluble protein content was determined according to Bradford (28), using bovine albumin serum as a standard.

\section{Statistical analysis}

The results of each assay were compared by analysis of variance (ANOVA), Newman-Keuls test using the STATISTICA 8.0 (Stat Soft Inc., USA) software package. Differences between corresponding controls and exposed samples were considered statistically significant at $\mathrm{P}<0.05$. Each data point is the average of six replicates unless stated otherwise.

\section{RESULTS}

\section{Cd and Cu content}

On day 4 of the experiment, $\mathrm{Cd}$ content in plants exposed to $5 \mu \mathrm{mol} \mathrm{L}{ }^{-1} \mathrm{Cd}$ alone was significantly higher than in plants exposed to either combination of $\mathrm{Cd}$ and $\mathrm{Cu}$ (Table 1). The combination of $\mathrm{Cd}$ and $\mathrm{Cu}$ in the higher concentration $\left(5.0 \mu \mathrm{mol} \mathrm{L}{ }^{-1}\right)$ significantly decreased $\mathrm{Cd}$ content in comparison to the combination the lower $\mathrm{Cu}$ concentration $\left(2.5 \mu \mathrm{mol} \mathrm{L} \mathrm{L}^{-1}\right)$ and even more distinctly to $\mathrm{Cd}$ alone. $\mathrm{Cu}$ was the highest in duckweed exposed to $\mathrm{Cu}$ alone in the higher concentration $(5.0 \mu \mathrm{mol} \mathrm{L}-1)$, while in combination with $\mathrm{Cd}$, it was significantly lower. The lowest $\mathrm{Cu}$ content was measured in plants exposed to $2.5 \mu \mathrm{mol} \mathrm{L}-1 \mathrm{Cu}$, alone or in combination with $\mathrm{Cd}$.
On day 7, Cd content showed the same behaviour as on day 4. The highest $\mathrm{Cu}$ content was observed in plants exposed to $5 \mu \mathrm{mol} \mathrm{L}{ }^{-1} \mathrm{Cu}$ alone, while it was significantly lower in plants exposed to the combination of $5 \mu \mathrm{mol} \mathrm{L}{ }^{-1} \mathrm{Cu}$ and $\mathrm{Cd}$. $\mathrm{Cu}$ content in plants exposed to $2.5 \mu \mathrm{mol} \mathrm{L^{-1 }} \mathrm{Cu}$ alone was significantly lower than in plants exposed to $5 \mu \mathrm{mol} \mathrm{L} \mathrm{L}^{-1}$ $\mathrm{Cu}$ either alone or in combination with $\mathrm{Cd}$. However, in comparison to combined exposure to $2.5 \mu \mathrm{mol} \mathrm{\textrm {L } ^ { - 1 }}$ $\mathrm{Cu}$ and $\mathrm{Cd}$ it was significantly higher (Table 1).

In plants not exposed to $\mathrm{Cd}$ (control and $\mathrm{Cu}$ treated plants), Cd content was below the instrument LOQ $\left(<0.001 \mu \mathrm{g} \mathrm{g}^{-1}\right)$. The same goes for $\mathrm{Cu}$ content in plants not exposed to $\mathrm{Cu}$ (control and $\mathrm{Cd}$-treated plants, $\left.<0.02 \mu \mathrm{g} \mathrm{g}^{-1}\right)$.

\section{Lipid peroxidation and protein oxidation}

MDA level was significantly higher in all treated plants than in control plants on both days 4 and 7 of the experiment. On day 4, the highest MDA was observed in plants exposed to a combination of $5 \mu \mathrm{mol} \mathrm{L}-1 \mathrm{Cu}$ and $\mathrm{Cd}$. Very high MDA levels were also measured in plants treated with $2.5 \mu \mathrm{mol} \mathrm{L}-1 \mathrm{Cu}$ alone, but were similar between other treatments (Figure 1).

On day 7, the highest MDA was observed in plants exposed to $\mathrm{Cu}$ alone in either concentration. MDA levels dropped in plants exposed to to the combination of $5 \mu \mathrm{mol} \mathrm{L}-1 \mathrm{Cu}$ and $\mathrm{Cd}$, and even more to the combination of $2.5 \mu \mathrm{mol} \mathrm{L}-1 \mathrm{Cu}$ and $5 \mu \mathrm{mol} \mathrm{L}-1 \mathrm{Cd}$, yet these values were still significantly higher than in control plants (Figure 1).

Table 1 Cadmium and copper content in Lemna minor L. on days 4 and 7 of exposure to Cd $\left(5.0 \mu m o l L^{-1}\right)$ and Cu $\left(2.5 \mu m o l L^{-1}\right.$ and $\left.5.0 \mu \mathrm{mol} \mathrm{L}^{-1}\right)$ and their combinations. In some samples, $C d$ and $C u$ were below the instrument's detection below the instrument's limit of quantification ( $L O Q ;<0.001 \mu \mathrm{g} \mathrm{g} \mathrm{g}^{-1}$ and $<0.02 \mu \mathrm{g} \mathrm{g}^{-1}$, respectively). The values are expressed as means $\pm S E$ of at least four replicates from two individual experiments $\pm S E$. Significant differences $(P<0.05$, NewmanKeuls test) between days 4 and 7 are marked with different letters.

\begin{tabular}{|c|c|c|c|}
\hline & Treatments & $\begin{array}{c}\mathrm{Cd} / \\
\mu \mathrm{g} \mathrm{g} \mathrm{g}^{-1} \text { dry weight }\end{array}$ & $\begin{array}{c}\mathrm{Cu} / \\
\mu g \mathrm{~g}^{-1} \text { dry weight }\end{array}$ \\
\hline \multirow{6}{*}{ Day 4} & Control & $<\mathrm{LOQ}^{\mathrm{a}}$ & $<\mathrm{LOQ}^{\mathrm{a}}$ \\
\hline & $\mathrm{Cd} 5.0 \mu \mathrm{mol} \mathrm{L}^{-1}$ & $834.32^{d} \pm 33.66$ & $<\mathrm{LOQ}^{\mathrm{a}}$ \\
\hline & $\mathrm{Cu} 2.5 \mu \mathrm{mol} \mathrm{L}^{-1}$ & $<\mathrm{LOQ}^{\mathrm{a}}$ & $244.71^{b} \pm 25.53$ \\
\hline & $\mathrm{Cu} 5.0 \mu \mathrm{mol} \mathrm{L}^{-1}$ & $<\mathrm{LOQ}^{\mathrm{a}}$ & $363.81^{\mathrm{d}} \pm 14.71$ \\
\hline & $\mathrm{Cu} 2.5 \mu \mathrm{mol} \mathrm{L}{ }^{-1}+\mathrm{Cd} 5.0 \mu \mathrm{mol} \mathrm{L}^{-1}$ & $536.1^{\mathrm{c}} \pm 65.86$ & $232.22^{\mathrm{b}} \pm 17.71$ \\
\hline & $\mathrm{Cu} 5.0 \mu \mathrm{mol} \mathrm{L}{ }^{-1}+\mathrm{Cd} 5.0 \mu \mathrm{mol} \mathrm{L}^{-1}$ & $431.54^{b} \pm 11.65$ & $310.9^{c} \pm 9.76$ \\
\hline \multirow{6}{*}{ Day 7} & Control & $<\mathrm{LOQ}^{\mathrm{a}}$ & $<\mathrm{LOQ}^{\mathrm{a}}$ \\
\hline & $\mathrm{Cd} 5.0 \mu \mathrm{mol} \mathrm{L}^{-1}$ & $1055.64^{\mathrm{d}} \pm 37.94$ & $<\mathrm{LOQ}^{\mathrm{a}}$ \\
\hline & $\mathrm{Cu} 2.5 \mu \mathrm{mol} \mathrm{L}^{-1}$ & $<\mathrm{LOQ}^{\mathrm{a}}$ & $342.91^{\mathrm{c}} \pm 36.36$ \\
\hline & $\mathrm{Cu} 5.0 \mu \mathrm{mol} \mathrm{L}^{-1}$ & $<\mathrm{LOQ}^{\mathrm{a}}$ & $480.98^{\mathrm{e}} \pm 27.82$ \\
\hline & $\mathrm{Cu} 2.5 \mu \mathrm{mol} \mathrm{L}{ }^{-1}+\mathrm{Cd} 5.0 \mu \mathrm{mol} \mathrm{L}^{-1}$ & $808.84^{c} \pm 52.44$ & $264.51^{b} \pm 12.11$ \\
\hline & $\mathrm{Cu} 5.0 \mu \mathrm{mol} \mathrm{L}{ }^{-1}+\mathrm{Cd} 5.0 \mu \mathrm{mol} \mathrm{L}^{-1}$ & $698.81^{\mathrm{b}} \pm 60.3$ & $405.87^{\mathrm{d}} \pm 18.43$ \\
\hline
\end{tabular}




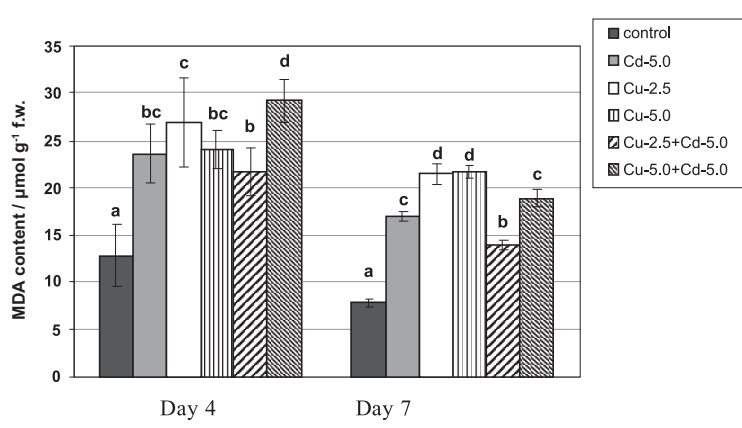

Figure 1 Differences in MDA levels on days 4 and 7 of the experiment. Values are expressed as means $\pm S E$, based on six replicates. Different column letters indicate significant differences at $P<0.05$ according to the Newman-Keuls test.

On day 4, carbonyl level, indicating oxidative damage to proteins, was higher in the exposed plants than in controls, but not significantly.

On day 7, however, it increased significantly in plants treated with $\mathrm{Cu}$ alone and with the combination of $5 \mu \mathrm{mol} \mathrm{L}-1 \mathrm{Cu}$ and $\mathrm{Cd}$ (Figure 2).

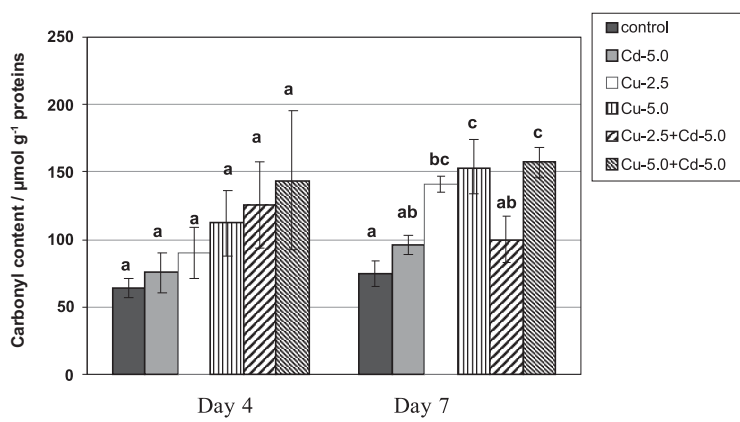

Figure 2 Differences in protein carbonyl levels on days 4 and 7 of the experiment. Values are expressed as means $\pm S E$, based on six replicates. Different column letters indicate significant differences at $P<0.05$ according to the Newman-Keuls test.

\section{Effect on DNA}

On day 4, the percentage of tail DNA showed a significant DNA damage in duckweed exposed to $\mathrm{Cd}$ alone or to both combinations with $\mathrm{Cu}$. $\mathrm{Cu}$ alone, however, did not show any genotoxic effect.

On day 7, DNA damage in plants exposed to $\mathrm{Cu}$ alone soared significantly at either concentration. Interestingly, in plants exposed to $\mathrm{Cu}$ and $\mathrm{Cd}$ combinations the level of DNA damage dropped significantly to values similar to control (Figure 3).

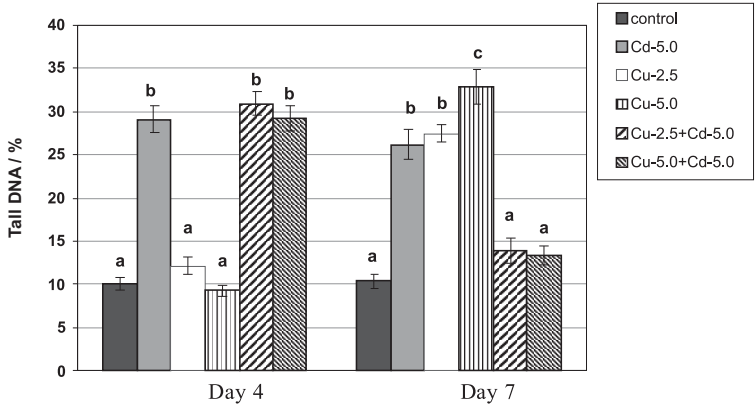

Figure 3 Differences in percentage of tail DNA on days 4 and 7 of the experiment. Values are expressed as means \pm SE, based on six replicates. Different column letters indicate significant differences at $P<0.05$ according to the Newman-Keuls test.

\section{Effect on antioxidant enzyme activity}

On day 4, CAT significantly rose in plants treated with $\mathrm{Cd}$ alone in respect to control and $\mathrm{Cu}$-exposed plants. However, absolutely the highest CAT activity was recorded in plants exposed to either combination (Figure 4A).

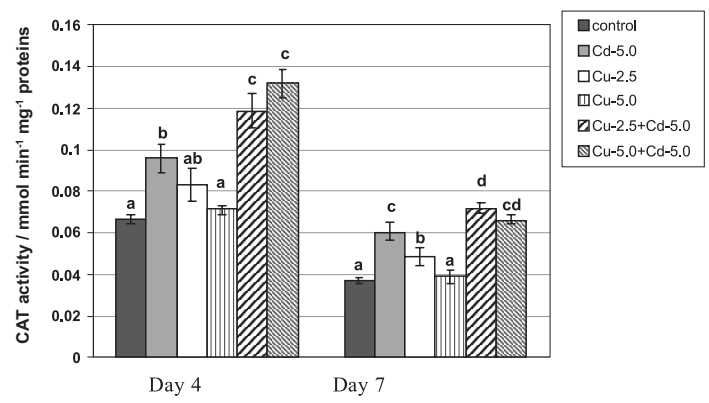

B

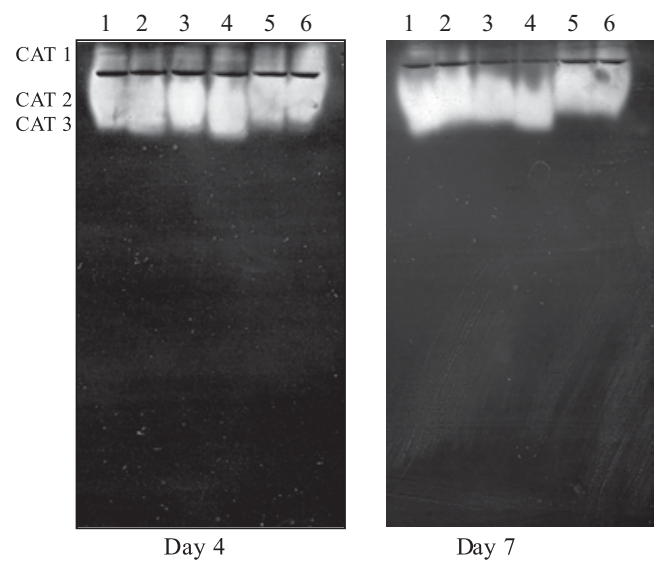

Figure 4 Differences in A) CAT activity on days 4 and 7 of the experiment. Values are expressed as means $\pm S E$, based on six replicates. Different column letters indicate significant differences at $P<0.05 \mathrm{~B}$ ) Isoenzyme pattern of CAT on days 4 and 7. Equal amounts of proteins $(100 \mu \mathrm{g})$ were loaded on the gel. 1 - control; 2 - Cd $5.0 \mu \mathrm{mol} \mathrm{L} L^{-1} ; 3$ - Cu $2.5 \mu \mathrm{mol}$ $L^{-1} ; 4$ - Cu $5.0 \mu \mathrm{mol} \mathrm{L} L^{-1} ; 5$ - Cd $5.0 \mu \mathrm{mol} \mathrm{L} L^{-1}+C u$ $2.5 \mu \mathrm{mol} \mathrm{L}{ }^{-1} ; 6$ - Cd $5.0 \mu \mathrm{mol} \mathrm{L} L^{-1}+C u 5.0 \mu \mathrm{mol} \mathrm{L}{ }^{-1}$ 
Similar results were recorded on day 7 (Figure 4A).

Electrophoresis revealed three CAT isoenzymes, which were marked as CAT1-CAT3, according to their rising mobility (Figure 4B). Isoforms CAT1 and CAT3 were common to control plants and plants treated with either $\mathrm{Cd}$ alone or $\mathrm{Cu}$ alone in both concentrations. Plants exposed to the combination of $\mathrm{Cd}$ and $\mathrm{Cu}$ revealed additional CAT2 isoenzyme and lacked isoform CAT3.

POD activity on day 4 significantly increased in plants treated with $\mathrm{Cd}$ alone and $\mathrm{Cu}$ alone at the lower concentration in comparison to control plants and plants treated with $\mathrm{Cd}$ and $\mathrm{Cu}$ at the lower concentration (Figure 5A). The highest POD activity was observed in plants treated with $\mathrm{Cd}$ and $\mathrm{Cu}$ at the higher concentration.

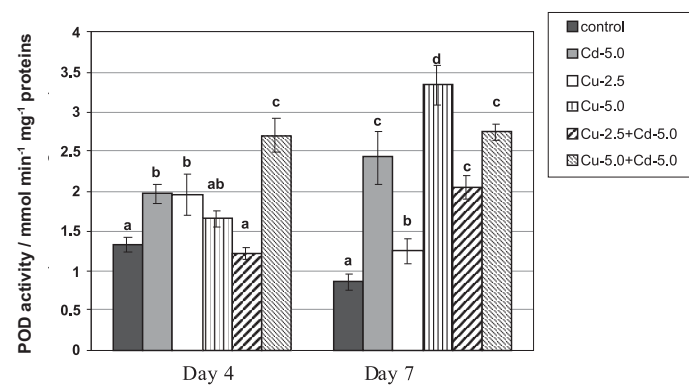

B

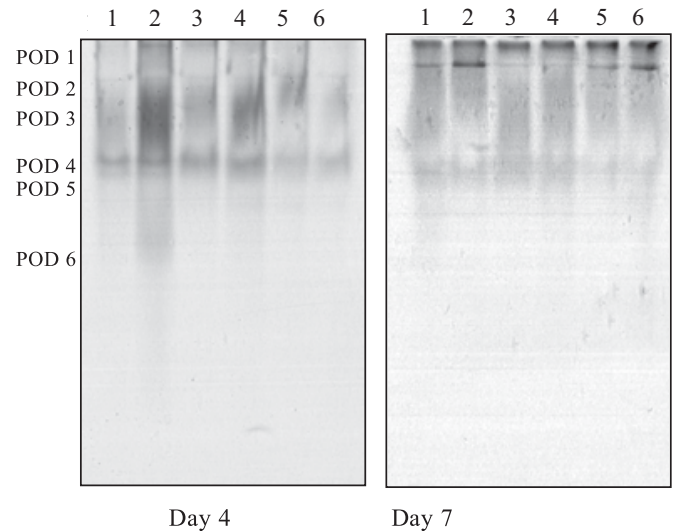

Figure 5 Differences in A) POD activity on days 4 and 7 of the experiment. Values are expressed as means $\pm S E$, based on six replicates. Different column letters indicate significant differences at $P<0.05$ according to the Newman-Keuls test. B) Isoenzyme pattern of $P O D$ on days 4 and 7. Equal amounts of proteins $(100 \mu \mathrm{g})$ were loaded on the gel. 1 - control; 2 - Cd 5.0 umol L ${ }^{-1} ; 3$ - Cu $2.5 \mu_{m o l ~ L}^{-1} ; 4$ - Cu 5.0 umol $L^{-1} ; 5$ - Cd $5.0 \mu \mathrm{mol} \mathrm{L}{ }^{-1}+C u 2.5 \mu \mathrm{mol} \mathrm{L} L^{-1} ; 6-C d$ $5.0 \mu \mathrm{mol} \mathrm{L} L^{-1}+C u 5.0 \mu \mathrm{mol} \mathrm{L} L^{-1}$

On day 7, all treated plants exhibited higher POD activity than control plants; the highest POD activity was observed with $\mathrm{Cu}$ at the higher concentration $\left(5.0 \mu \mathrm{mol} \mathrm{L}{ }^{-1}\right) . \mathrm{Cd}$ and both $\mathrm{Cd} / \mathrm{Cu}$ combinations produced similar POD activities, which were higher than the one with $2.5 \mu \mathrm{mol} \mathrm{L}^{-1} \mathrm{Cu}$ alone (Figure $5 \mathrm{~A})$.

On day 4, six POD isoforms were detected and marked as POD1-POD6 according to their rising mobility (Figure 5B). Treatment with $\mathrm{Cd}$ yielded the highest POD2 and POD3 in-gel activity. Isoforms POD1-POD5 were present in all samples, while POD6 was appeared with $\mathrm{Cd}$ treatment only.

On day 7, isoform POD1 gave a stronger signal in all samples than on day 4 , while POD2 was more pronounced in $\mathrm{Cd}$ and both $\mathrm{Cd} / \mathrm{Cu}$ combinations. Isoform POD6 was not found in samples treated with Cd alone.

\section{DISSCUSION}

Cadmium and copper are important environmental pollutants, especially to aquatic ecosystems. Although they differ in biological significance, higher concentrations of these metals are toxic and disturb plant metabolism. The choice of $\mathrm{Cd}$ concentration in this study relies on findings from a previous study (29), while the choice of $\mathrm{Cu}$ concentrations is based on preliminary experiments yielding reduced growth, but without chlorosis.

Our study has shown that both metals tend to accumulate with time, but also that in combination, they affect each other's uptake. The higher $\mathrm{Cu}$ concentration of $5.0 \mu \mathrm{mol} \mathrm{L}^{-1}$ was more effective in inhibiting $\mathrm{Cd}$ uptake than the lower $\mathrm{Cu}$ concentration of $2.5 \mu \mathrm{mol} \mathrm{L}-1$. Generally, plants do not absolutely discriminate between important micronutrients and nonessential metals, and different metals may share the same transporters across the cell membrane (30).

Given the complexity of the transmembrane transport of metals, further studies at molecular level are needed to understand the mechanism underlying this phenomenon (30). Semsari et al. (31) have shown that Lemna gibba removes $\mathrm{Cd}$ from the growth medium in linear and concentration-dependent manner, but with $\mathrm{Zn}$ and $\mathrm{Cu}$ the removal is biphasic, with a quick and slow phase. Kwan and Smith (32) have shown that $\mathrm{Ca}$ affects $\mathrm{Cd}$ accumulation in Lemna minor. A study with other macrophytes has also suggested that micronutrients are taken up by plants faster than nonessential heavy metals (33).

On the other hand, metal combinations supplemented to growth media can interact and affect each other's accumulation (34), but interaction does not necessarily 
coincide with the bioaccumulation pattern (35). This is why we analysed various oxidative stress parameters, to get a better understanding of $\mathrm{Cu}-\mathrm{Cd}$ interaction.

Lipid peroxidation, which diminishes the integrity of cells and organelle membranes, is one of the most significant effects of heavy metals in plants $(12$, 36). Increased MDA level is considered a general indicator of oxidative stress (37). Increased MDA has already been found in L. minor and other species after exposure to $\mathrm{Cd}(38,29)$ or $\mathrm{Cu}(13)$. Our results have shown significantly higher MDA in all exposed plants as early as day 4. The highest MDA content found in plants treated with a combination of $\mathrm{Cd}$ and $5 \mu \mathrm{mol} \mathrm{L}-1 \mathrm{Cu}$ may point to a synergistic effect. On day 7, however, the highest MDA level was found in plants treated with $\mathrm{Cu}$ alone, while it dropped in plants treated with metal combinations. This points to a reduction in oxidative stress in plants treated with the metal combinations, which could correlate with higher CAT activity.

In plants exposed to heavy metals, protein levels are often lower in consequence of lower $\mathrm{Mg}$ and $\mathrm{K}$ uptake, nutrients important for protein synthesis (38). Oxidative damage to proteins was measured using carbonyl as a biomarker. When oxidised, proteins change their native conformation as well as activity level (39). This could mean that proteins are more susceptible to oxidative damage by $\mathrm{Cu}$ than by $\mathrm{Cd}$, probably due to direct ROS production in the presence of $\mathrm{Cu}(10)$.

Comet assay showed a significant increase in DNA damage in $\mathrm{Cd}$ alone-treated plants throughout the experiment. $\mathrm{Cu}$ alone was genotoxic only on day 7. Interestingly, $\mathrm{Cu}$ combined with $\mathrm{Cd}$ showed the opposite behaviour; on day 4, DNA damage was high, only to plunge on day 7 . Unfortunately, the comet assay, being a quantitative method, does not shed any light on the mechanism underlying this behaviour or metal genotoxicity as such. Our lipid peroxidation and carbonyl level findings suggest that metal damage DNA indirectly, that is, through oxidative stress. The same was observed by Gichner et al. (6) and Valverde et al. (40). This is supported by a drop in DNA damage in plants exposed to $\mathrm{Cu} / \mathrm{Cd}$ combinations on day 7 , which correlates with lower MDA level (Figure 1). The drop may also be attributed to DNA repair (41).

$\mathrm{H}_{2} \mathrm{O}_{2}$-scavenging enzymes CAT and POD have an important role in plant response to oxidative stress. Catalase is located in peroxisomes and its very high reaction rate turns it into an effective cellular sink for $\mathrm{H}_{2} \mathrm{O}_{2}$, despite its poor affinity for the molecule (42). Guaiacol peroxidase is located in cytosol, vacuole, cell wall, and extracellular space. Having a considerably higher affinity for $\mathrm{H}_{2} \mathrm{O}_{2}$ than catalase, $\mathrm{POD}$ requires a reductant, a substrate to be oxidised during $\mathrm{H}_{2} \mathrm{O}_{2}$ scavenging (43). Both CAT and a variety of peroxidases seem to have an important role in controlling $\mathrm{H}_{2} \mathrm{O}_{2}$. The enzymes are activated in response to elevated ROS as part of plant defence mechanism, although decline or inhibition of their activity has been also noticed under severe stress (29). In some plants, $\mathrm{Cd}$ and $\mathrm{Cu}$ are known to increase CAT and POD activity $(29,36,44)$. In our study, CAT showed similar activity pattern on days 4 and 7. $\mathrm{Cd}$ alone caused a significant rise in CAT activity in comparison to control and $\mathrm{Cu}$-treated plants. Previous studies in duckweeds have also indicated concentration-dependent changes in CAT activity after treatment with $\mathrm{Cd}$ or $\mathrm{Cu}(16,38)$. In our study, both $\mathrm{Cu} / \mathrm{Cd}$ combinations provoked the highest $\mathrm{CAT}$ activity, regardless of exposure time. This suggests that metal combinations are more stressful to plants than individual metals. This is further confirmed by the presence of isoenzyme CAT2 and absence of CAT3 in plants treated with metal combinations. Unlike CAT isoenzymes, changes in the number of POD isoenzymes were observed only in Cd-treated plants.

$\mathrm{Cu}$ and $\mathrm{Cd}$ are known to generate ROS in different manner, which could explain the differences between their effects. $\mathrm{Cu}$ is a redox-active metal, which catalyses hydroxyl radical production via Haber-Weis reaction, while Cd indirectly increases ROS load by binding to functional protein group, which eventually disrupts protein structure and inhibits protein activity. Yeh et al. (45) have shown that differences between $\mathrm{Cu}$ and $\mathrm{Cd}$ in generating ROS may produce different intracellular heavy metal stress signalling networks. Tkalec et al. (29) have also proposed that $\mathrm{H}_{2} \mathrm{O}_{2}$ signaltransducing molecule may be responsible for enhanced CAT and POD activities in L. minor exposed to $\mathrm{Cd}$ for a long time.

\section{CONCLUSION}

In this study, $\mathrm{Cd}$ and $\mathrm{Cu}$, when in combination, reduced each other's uptake. Both metals were toxic/ genotoxic to duckweed and caused oxidative stress when added to medium alone, but in combination they showed a more complex response that can not be explained by simple antagonism and/or synergism. Further studies should go in that direction. 


\section{REFERENCES}

1. Qian H, Li J, Sun L, Chen W, Sheng GD, Liu W, Fu Z. Combined effect of copper and cadmium on Chlorella vulgaris growth and photosynthesis-related gene transcription. Aquat Toxicol 2009;94:56-61.

2. Wilde KL, Stauber JL, Markich SJ, Franklin NM, Brown PL. The effect of $\mathrm{pH}$ on the uptake and toxicity of copper and zinc in a tropical freshwater alga (Chlorella sp.). Arch Environ Contam Toxicol 2006; 51:174-85.

3. Sanita di Toppi L, Gabbrielli R. Response to cadmium in higher plants. Environ Exp Bot 1999;41:105-30.

4. Jin YH, Clark AB, Slebos RJC, Al-Refai H, Taylor JA, Kunkel TA, Resnick MA, Gordenin DA. Cadmium is a mutagen that acts by inhibiting mismatch repair. Nat Genet 2003;34:326-9

5. Rodríguez-Serrano M, Romero-Puertas MC, Zabalza A, Corpas FJ, Gómez M, del Río LA, Sandalio LM. Cadmium effect on oxidative metabolism of pea (Pisum sativum L.) roots. Imaging of reactive oxygen species and nitric oxide accumulation in vivo. Plant Cell Environ 2006;29:153244.

6. Gichner T, Patková Z, Száková J, Demnerová K. Cadmium induces DNA damage in tobacco roots, but no DNA damage, somatic mutations or homologous recombination in tobacco leaves. Mutat Res 2004;559:49-57.

7. Ünyayar S, Celik A, Cekic OF, Gozel A. Cadmium induced genotoxicity, cytotoxicity and lipid peroxidation in Allium sativum and Vicia faba. Mutagenesis 2006;21:77-81.

8. Chugh LK, Sawhney SK. Photosynthetic activities of Pisum sativum seedlings grown in presence of cadmium. Plant Physiol Biochem 1999;37:297-303.

9. Prasad SM, Dwivedi R, Zeeshan M, Singh R. UV-B and cadmium induced changes in pigments, photosynthetic electron transport activity, antioxidant levels and antioxidative enzyme activities of Riccia sp. Acta Physiol Plant 2004;26:423-30.

10. Welch RM. Micronutrient nutrition of plants. Crit Rev Plant Sci 1995; 14:49-82.

11. Frankart C, Eullaffroy P, Vernet G. Photosynthetic responses of Lemna minor exposed to xenobiotics, copper, and their combinations. Ecotoxicol Environ Saf 2002;53:439-45.

12. Schützendübel A, Polle A. Plant responses to abiotic stresses: heavy metal induced oxidative stress and protection by mycorrhization. J Exp Bot 2002;53:1351-65.

13. Razinger J, Dermastia M, Drinovec L, Drobne D, Zrimec A, Dolenc Koce J. Antioxidative responses of duckweed (Lemna minor L.) to short-term copper exposure. Environ Sci Pollut Res 2007;14:194-201.

14. Wang WC, Freemark K. The Use of plants for environmental monitoring and assessment. Ecotoxicol Environ Saf 1995;30:289-301.

15. Blinova I. Use of freshwater algae and duckweeds for phytotoxicity testing. Environ Toxicol 2004;19:425-8.

16. Drost W, Matzke M, Backhaus T. Heavy metal toxicity to Lemna minor: studies on the time dependence of growth inhibition and the recovery after exposure. Chemosphere 2007:67:36-43.

17. Mohan BS, Hosetti BB. Potential phytotoxicity of lead and cadmium to Lemna minor grown in sewage stabilization ponds. Environ Pollut 1997;98:233-8.
18. Kara Y. Bioaccumulation of copper from contaminated wasterwater by using Lemna minor. Bull Environ Contam Toxicol 2004;72:467-71.

19. Maine MA, Duarte MV, Sune NL. Cadmium uptake by floating macrophytes. Water Res 2001;35:2629-34.

20. International Organization for Standardization (ISO). Determination of the toxic effect of water constituents and wastewater on duckweed (Lemna minor) - Duckweed growth inhibition test, ISO norm 20079; 2006.

21. Pirson A, Seidel F. Zell- und stoffwechselphysiologiche Untersuchungen an der Wurzel von Lemna minor unter besonderer Berücksichtigung von Kalium- und Calciummangel [Cell metabolism and physiology in Lemna minor root deprived of potassium and calcium, in German]. Planta 1950;38:431-73.

22. International Organization for Standardization (ISO). Water quality - determination of the toxic effect of water constituents and waste water to duckweed (Lemna minor) - Duckweed growth inhibition test. ISO TC 147/SC 5/WG $5,2004$.

23. Heath RL, Packer L. Photoperoxidation in isolated chloroplasts. I. Kinetics and stoichiometry of fatty acid peroxidation. Arch Biochem Biophys 1968;125:189-98.

24. Levine RL, Williams JA, Stadtman ER, Shacter E. Carbonyl assay for determination of oxidatively modified proteins. Method Enzymol 1994;233:346-57.

25. Aebi M. Catalase in vitro. Method Enzymol 1984;105:1216.

26. Woodbury WA, Spencer K, Stahlmann MA. An improved procedure using ferricyanide for detecting catalase isozymes. Anal Biochem 1971;44:301-5.

27. Chance B, Maehly AC. Assay of catalases and peroxidases. In: Colowick SP, Kaplan NO, editors. Methods in enzymology. New York (NY): Academic Press; 1955. p.764-75.

28. Bradford MM. A rapid and sensitive method for the quantitation of microgram quantities of protein utilizing the principle of protein-dye binding. Anal Biochem 1976;72:24854.

29. Tkalec M, Prebeg T, Roje V, Pevalek-Kozlina B, Ljubešić N. Cadmium-induced responses in duckweed Lemna minor L. Acta Physiol Plant 2008;30:881-90.

30. Verkleij JAC, Golan-Goldhirshb A, Antosiewiszc DA, Schwitzguébel J-P, Schrödere P. Dualities in plant tolerance to pollutants and their uptake and translocation to the upper plant parts. Environ Exp Bot 2009;67:10-22.

31. Semsari M, Couderchet M. Toxicity and removal of heavy metals (cadmium, copper, and zinc) by Lemna gibba. Ecotoxicol Environ Saf 2009; 72:1774-80.

32. Kwan KHM, Smith S. Some aspects of the kinetics of cadmium uptake by fronds of Lemna minor L. New Phytol 1991;117:91-102.

33. Mishra VK, Tripathi BD, Concurrent removal and accumulation of heavy metals by three aquatic macrophytes. Bioresource Technol 2008;99:7091-7.

34. Yizong H, Ying H, Yunxia L. Heavy metal accumulation in iron plaque and growth of rice plants upon exposure to single and combined contamination by copper, cadmium and lead. Acta Ecol Sin 2009;29:320-6.

35. An YJ, Kim YM, Kwon TI, Jeong SW. Combined effect of copper, cadmium, and lead upon Cucumis sativus growth and bioaccumulation. Sci Total Environ 2004;326:85-93.

36. Singh S, Eapen S, D'Souza SF. Cadmium accumulation and its influence on lipid peroxidation and antioxidative system 
in an aquatic plant, Bacopa monnieri L. Chemosphere 2006;62:233-46.

37. Cho U-H, Seo N-H. Oxidative stress in Arabidopsis thaliana exposed to cadmium is due to hydrogen peroxide accumulation. Plant Sci 2005;168:113-20.

38. Hou W, Chen X, Song G, Wang Q, Chang CC. Effects of copper and cadmium on heavy metal polluted waterbody restoration by duckweed (Lemna minor). Plant Physiol Biochem 2007;45:62-9.

39. Stadtman ER. Protein oxidation and aging. Free Radic Res 2006;40:1250-8.

40. Valverde M, Trejo C, Rojas E. Is the capcity of lead acetate and cadmium chloride to induce genotoxic damage due to direct-metal interaction? Mutagenesis 2001;16:265-70.

41. Pincheiraa J, López-Sáez JF, Carrerab P, Navarrete MH, de la Torre C. Effect of caffeine on in vivo processing of alkylated bases in proliferating plant cells. Cell Biol Int 2003;27:83743.

42. Willekens H, Chamnongpol S, Davey M, Schraudner M, Langebartels C, van Montagu M, Inze D, van Camp W. Catalase is a sink for $\mathrm{H}_{2} \mathrm{O}_{2}$ and is indispensable for stress defence in C3 plants. EMBO J 1997;16:4806-16.

43. Verma S, Dubey RS. Lead toxicity induces lipid peroxidation and alters the activities of antioxidant enzymes in growing rice plants. Plant Sci 2003;164:645-55.

44. Dazy M, Masfaraud JF, Férard JF. Induction of oxidative stress biomarkers associated with heavy metal stress in Fontinalis antipyretica Hedw. Chemosphere 2009;75:297302.

45. Yeh C-M, Chien P-S, Huang H-J. Distinct signalling pathways for induction of MAP kinase activities by cadmium and copper in rice roots. J Exp Bot 2007;58:659-71. 


\section{Sažetak \\ UČINAK BAKRA NA TOKSIČNOST I GENOTOKSIČNOST KADMIJA U VODENOJ LEĆI (LEMNA MINOR L.)}

U svrhu istraživanja interakcija između bakra kao esencijalnog elementa te kadmija kao neesencijalnog i toksičnog metala, vodenu leću Lemna minor L. uzgajali smo na podlogama s kadmijem $\left(5 \mu \mathrm{mol} \mathrm{L}^{-1}\right)$ odnosno s bakrom $\left(2,5 \mu \mathrm{mol} \mathrm{L}^{-1}\right.$ i $\left.5 \mu \mathrm{mol} \mathrm{L}^{-1}\right)$ te s njihovim kombinacijama. Unos metala u biljke povećavao se s trajanjem pokusa, a kod kombinacije metala u biljkama je izmjerena niža količina kadmija nego u onima uzgajanima samo na kadmiju. U biljkama tretiranim pojedinačnim metalom došlo je do povećanja sadržaja malondialdehida (MDA) te aktivnosti katalaze i peroksidaze u odnosu na kontrolne biljke. Također, primijećeno je oštećenje DNA iako kod bakra tek sedmog dana tretmana. Količina MDA i aktivnost obaju enzima dodatno se povećala na tretmanu kombinacijom kadmija i bakra $\left(5 \mu \mathrm{mol} \mathrm{L}^{-1}\right)$ nakon četvrtog dana pokusa, dok se količina MDA smanjila nakon sedmog dana kod kombinacije kadmija i 2,5 $\mu \mathrm{mol} \mathrm{L}^{-1}$ bakra. U tim biljkama primijećena je i veća aktivnost katalaze, dok je aktivnost peroksidaze porasla na tretmanu kadmijem i 2,5 $\mu \mathrm{mol} \mathrm{L}^{-1}$ bakrom, ali se smanjila na tretmanu kadmijem i $5 \mu \mathrm{mol} \mathrm{\textrm {L } ^ { - 1 }}$ bakrom. Oštećenje DNA koje je bilo veće kod kombinacije metala nakon četvrtog dana, osobito u usporedbi sa samim bakrom, smanjilo se nakon sedmog dana pokusa. Iz ovih rezultata može se zaključiti da su oba metala u istraživanim koncentracijama toksična i genotoksična za vodenu leću i da uzrokuju oksidacijski stres. Kadmij u kombinaciji s bakrom više koncentracije bio je toksičniji od pojedinačnih metala nakon četvrtog dana pokusa, dok su u biljaka tretiranih kombinacijom kadmija i bakra niže koncentracije toksični učinci bili manji. Budući da su primijećene interakcije vrlo kompleksne i ne uključuju samo antagonizam odnosno sinergizam potrebna su daljnja istraživanja.

KLJUČNE RIJEČI: ekotoksikološka analiza, oksidacijski stres, oštećenje DNA, teški metali, vodene biljke

\section{CORRESPONDING AUTHOR:}

Mirjana Pavlica, $\mathrm{PhD}$

Department of Molecular Biology

Faculty of Science, University of Zagreb

HR-10000 Zagreb, Horvatovac 102 a

E-mail: mpavlica@zg.biol.pmf.hr 